\title{
Developing Students' Problem-Solving Skills Using Learning Tasks: an Action Research Project in Secondary School
}

\author{
Martina Tóthová and Martin Rusek* \\ Charles University, Faculty of Education, Department of Chemistry and Chemistry Education, \\ Magdalény Rettigové 4, 11639 Praha \\ *Corresponding author: E-mail: martin.rusek@pedf.cuni.cz
}

Received: 07-29-2021

\begin{abstract}
Studies on students' problem-solving skills worldwide suggest there is a room for improvement. This study aimed at improving upper-secondary school students' problem-solving skills in chemistry lessons. They were given a problem tasks pre-test focused on their conceptual knowledge regarding the periodic table, ability to apply knowledge on the factors affecting chemistry reaction rate and compounds' properties. Most students (72 out of 112) did not succeed to solve the tasks. For this reason, an intervention was designed based on a study using eye-tracking combined with think-aloud. It consisted of students' working on (PISA-like) context-based chemistry problem tasks with a special scaffolding. A teacher provided formative assessment promoting students' expansive strategies. The intervention's effect was again assessed using problem tasks in two post-tests. The results showed the action plan was successful in helping the majority of students reach above-average test score. The ratio of successful solvers also rose and unsuccessful significantly declined.
\end{abstract}

Keywords: Chemistry education; action research; problem solving; students' skills development

\section{Introduction}

There is a significant gap between research (researchers) and school practice (teachers' understanding of the research). ${ }^{1,2}$ Teachers consider research and theory to be something remotely related to their actual practice. ${ }^{3}$ In action research, a teacher becomes an observer (e.g. in order to maintain objectivity). ${ }^{4}$ In this respect, action research seems to be one of the possible remedies as it combines academic research with practice, e.g. ${ }^{5,6}$ The teacher plans and systematically verifies the learning process, the teacher is a part of the research process and not only subject to investigation or a non-participating observer. ${ }^{3,4,7}$

The presented action research was guided by a definition by Cohen, et al., ${ }^{8}$ who point it out as an on-the-spot procedure which focuses on a specific problem located in a current situation. The process is ideally supposed to be monitored step-by-step using different tools (questionnaires, diaries, interviews, and case studies, for example).

Research on chemistry education mostly focuses either on lower-secondary or upper-secondary education, namely grammar schools, or at university level. There is, however, a numerous group of non-chemical vocational school students who have been neglected by researchers so far. ${ }^{9}$ They follow a curriculum which contains chemistry as a school subject of general education at schools oriented in various fields but science. Teaching chemistry at this level is influenced by several factors, such as students' attitudes to this subject - which is not the part of the school-leaving exam nor their study profile. ${ }^{10}$ Also, their school is considered lower success grammar school students. ${ }^{9}$ The curriculum for these schools is exempt from some of the content objectives in the field of chemistry. Nevertheless, the key competencies remain the same for different types of upper-secondary schools: Framework Educational Programme for Grammar school, ${ }^{11}$ Framework Educational Programme for Economic lyceum. ${ }^{12}$ With the students' focus in mind, the goal of chemistry education at this type of school remains mostly in skills (competences) development via the chemistry subject matter, however, the curricular objectives have the potential to stimulate the higher-order cognitive operations which should be included in the tasks students solve. ${ }^{13}$ This action research was therefore motivated by one of the $21^{\text {st }}$ century skills $\mathrm{cf}^{14}{ }^{14}$ - problem solving. As an integral aspect strongly linked with science education, problem solving belongs among widely 
studied phenomena. ${ }^{15-17}$ Its aim was to identify the state of students' problem-solving skills and to improve the strategies and skills necessary for problem solving. These can be, unlike problem solving itself, cultivated in schools. ${ }^{18}$

Problems in chemistry were elaborated by Johnstone. ${ }^{19}$ He classified eight types of problems according to the three variables: data, methods, goals. Type 1 (where data and goals are given, used methods are familiar) is the most used type of problem in chemistry and can be considered as "exercise" or algorithmic problems. ${ }^{20}$ Problems are not hierarchical and related to their difficulty. They can be also well-structured or ill structured. ${ }^{21,22}$ Some authors e.g. ${ }^{23}$ consider any chemical situation that students are not familiar with conceptual problems. This approach is taken in this paper.

When making international comparisons, Czech students achieve average results in surveys based on problem tasks. ${ }^{24,25}$ Other evidence of their skills can be drawn from the use of problem (indicator) tasks verifying the expected objectives' achievement. These tasks were verified ${ }^{26}$ and used to research the steps students used while solving these tasks. ${ }^{27}$ Even the results in this area do not show the success of these students. Moreover, they indicate so-called false-positive results when mere paper-testing is executed.

\section{Goals}

The aim of the action research was to increase non-chemical vocational school students' (age 15-16) ability to solve chemistry problem tasks. The research followed this research question (RQ):

How does the practice of general problem-solving strategies translate into students' ability to solve chemistry problem-tasks?

Successful task solution determines the student's ability to read and understand the assignment correctly. It requires a direct relationship with reading literacy ${ }^{28}$ and subsequently identifying the problem and choosing an appropriate strategy to solve it. ${ }^{29,30}$ It is therefore desirable to lead activities which develop both the students' skills and this ability in view of the level of the specific students' strategies.

The RQ is closely associated with the results from a qualitative study using eye-tracking and retrospective think-aloud to find students' strategies and problems. ${ }^{31}$ Eye-tracking has found a broad use in (science) education $^{32}$ including chemistry education. ${ }^{33-35}$ The action plan developed according to these research findings was subsequently tested.

\section{Methods}

\section{1. The Research Team}

The action research was attended not only by a teacher (the first author) as it is usual see ref., ${ }^{36}$ but was support- ed by a researcher (the second author). He helped the teacher choose appropriate research methods (namely eye-tracking and think-aloud), analyzed the data and was present at the realization of an intervention - teaching approach emphasizing problem solving strategies - as an observer and when needed, as a teaching assistant. This combination allows the researcher to use the teacher's practical knowledge, which is reflected in theory and analyzed based on the acquired data cf. ${ }^{4}$

\section{2. Eye-Tracking and Think aloud Methods}

Eye-tracking is a method based on eye movement recording. Its analysis reveals cognitive processes and mechanisms involved in visual perception..$^{32}$ It basically enables researchers observe what a subject fixates with their eyes, therefore processes in their mind. ${ }^{37}$ To understand the subject's cognitive processes in more detail, the thinkaloud method is being used..$^{31}$ Participants are asked to describe out loud their thought process when solving the task with no interruption of researcher. ${ }^{38}$ Combination of these methods thus enables researchers to explain the results in more detail, including reasons of failure, applied strategies etc.

\section{3. The Action Plan}

The action research was organized in typical steps ${ }^{39}$ (see Figure 1).

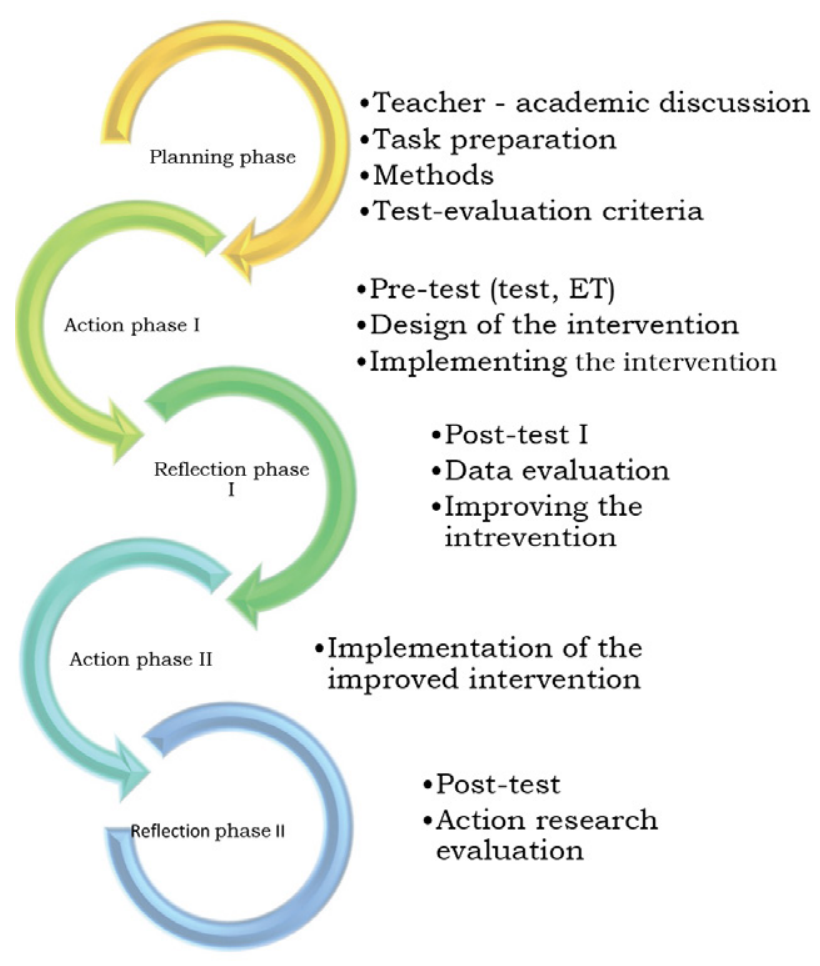

Figure 1. The action plan 


\section{Planning phase (June 2018)}

In the planning phase, the problems the teacher observed during chemistry lessons were discussed with the researcher (chemistry education expert/teacher trainer). Based on the literature, a possible method to intervene was proposed, and research questions were set (see Goals).

The methods to verify the students' skills initial status and the criterion to evaluate the success of the teaching approach emphasizing problem solving strategies were developed (see Action phase I).

Altogether, three tests of comparable difficulty containing three tasks each were developed. To prevent the negative effect of students' possible task recollection, different tasks were used. They were taken from Methodical commentary and tasks from the Standards for Basic Education - Chemistry ${ }^{40}$ - a publication adjacent to the Czech national curriculum. The tasks target the expected outcomes, i.e. lower-secondary curricular objectives. These tasks were complex task, formulated in a non-standard way for students. During solving, they can learn some information from the text, therefore are considered as problem-tasks, in accordance with other authors. ${ }^{19,23}$ To ensure the pre- and post-tests comparability, task-difficulty scores derived from an expert panel evaluation ${ }^{26}$ and further piloting ${ }^{26,27,41}$ were used to select the tasks for the test. The tasks were evaluated in a manner similar to PISA tasks, i.e. successful, partially successful and successful. Each task in the test was assigned a maximum of two points $(2-$ completely succesful, 1 - partially successful 0 - unsuccessful).

\section{Action phase I (September - December 2018)}

Pre-tests

This action research was planned in reaction to previous research results which showed deficiencies both in students' knowledge problem solving skills. ${ }^{31}$ Therefore, the prior study served as a pre-test. The students' knowledge and skills which they acquired in lower-secondary education, i.e. the starting point for chemistry teaching at secondary school was assessed using a set of three tasks. Also, as described in the prior study, ${ }^{31}$ based on the pretest out of 139 tested, eight students' problem-solving skills (strategies they employed and problems they faced when solving tasks) were further investigated using eye-tracking and retrospective think-aloud (RTA) method.
The pre-test consisted of three tasks. In the first task, the students worked with the periodic table of elements. Knowledge of the: proton number, oxidation number, conductivity (heat and electric), non-conductors, metals, metalloids, semi-metals as well as basic orientation in the periodic table (group, period) was tested. The task was to identify a certain group of elements based on their characteristics' description, i.e. all non-metal elements from the second period etc. A periodic table including a legend with the element groups was provided.

In the second task, students were supposed to apply their knowledge of the factors influencing chemistry reaction rate and work with a graph. They were provided a context which introduced them to a new hypothetical battery production. It contained an equation of manganese's reaction with hydrochloric acid and a graph of the reaction rate's dependency on time (see Figure 2). Their task was to match the following steps to the particular phases in the graph: adding $\mathrm{Mn}$, adding $25 \% \mathrm{HCl}$, adding $10 \% \mathrm{HCl}$ and heating. The students were also asked to justify their answer.

The third task concerned the physical properties of organic chemistry substances. It focused on the students' understanding of the properties and their application. The students were provided a table of melting and boiling points and the density of five substances (methane, toluene, benzene, isooctane, naphthalene), and were supposed to decide on particular statements (true or false) under laboratory conditions (temperature and atmospheric pressure): benzene is gas, isooctane is solid, naphthalene is solid, toluene is gas.

\section{Pre-test evaluation}

The pre-tests were evaluated according to the $\mathrm{Au}$ thors' key see. ${ }^{40}$ As the mere test evaluation can be insufficient to fully understand the reasons behind students' problems, 8 students at different levels of success were selected for a qualitative (ET) part of the study. This part of study used eye-tracking and think-aloud method and the methods - procedure of this qualitative part were already published elsewhere see. ${ }^{31}$ For action research's and mainly for the understanding's sake, the important results are summarized in this article. Students used following expansive and limiting strategies and faced these problems:

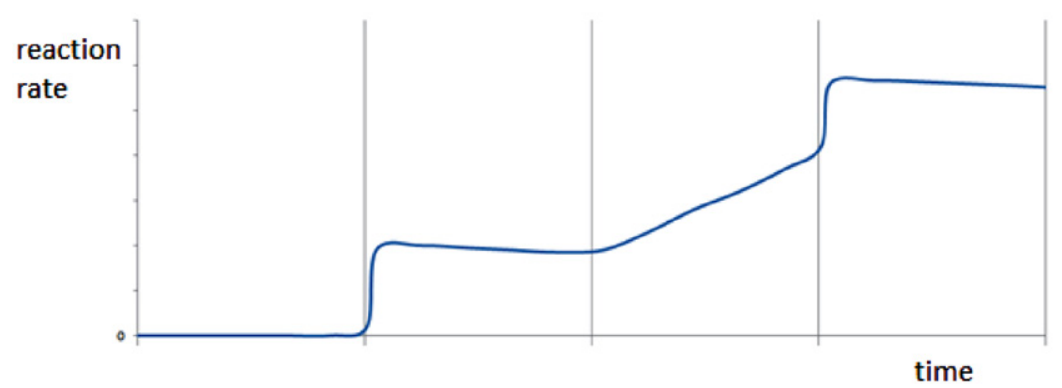

Figure 2. Graph from the second task 
Expansive strategies:

- Gradual chaining, ${ }^{42}$

- logical justification, ${ }^{43}$

- working with the information in the assignment, ${ }^{27}$

- self-reflection (working with error),$^{44}$

- finding a pattern - the principle of function. ${ }^{43}$

Limiting strategies:

- Guessing the result, ${ }^{45}$

- drawing conclusions from the assignment structure, $^{27}$

- memorization-based solutions. ${ }^{46}$

Problems:

- Problem identification (misunderstanding of input, inattentive reading, editing the assignment),

- motivation (giving up, not solving a task),

- inability to use knowledge,

- lack of knowledge.

The students struggled with reading (multiple cases). For example, in the task where the students were supposed to write a code consisting of proton numbers, they wrote the elements' symbols. The ability to read proved to be crucial. ${ }^{47}$ The students also struggled with motivation. This phenomenon most often occurred in a task in which they had to perform simple mathematical operations. Some students tended to answer by guessing when a task was more demanding - requiring several steps. There were students who had no idea about the term 'proton number' or who could not use the periodic table. This shows the curricular objectives of basic education in the field of chemistry were not reached with these students.

\section{Intervention preparation (January 2019)}

With respect to the identified strategies and problems, the action plan was designed to strengthen the use of expansive strategies and eliminate limiting strategies as well as target the missing functional knowledge regarding lower-secondary chemistry subject matter. ${ }^{48}$ The teaching approach emphasizing problem solving strategies was based on students working with tasks released from the PISA project, enriched by chemistry-oriented tasks of a similar nature.

\section{Action I (February - March 2019)}

The intervention took place one lesson (out of two in total) per week for two months. Students in groups (2-3 students) were given a set of released PISA tasks. These contextual, science-oriented tasks were used without any changes and were chosen due to students' problems ascertained in the above-mentioned eye-tracking/think-aloud study. ${ }^{31}$ They were mostly related to reading - finding the main problem to solve as well as the provided hints and variables. Added instructions led students to understanding the assignment better. Under the teachers' guidance, the following steps were taken: 1 . What is the task (what they have to answer, what will be the form of the answer), 2. Schedule the procedure, 3 . What data is provided (data needed). Students were also supposed to identify the causes of their mistakes (self-reflection strategy). Later during the action phase, the teacher performed them only with groups who did not express their willingness to try solving the tasks on their own first.

\section{Refslection phase}

Post-test I (March 2019)

After two months, in the end of action phase $I$, a post-test I was given to the students in order to measure the intervention's effect. The post-test I tasks contained tasks of a similar nature and difficulty to the pre-test. The tasks included student choice of an appropriate procedure (including quantity of individual substances, heating, cooling, etc.) that would be suitable for preparing a solution (food for bees). The second task was directed towards the students' scientific text reading skills. They were supposed to use information from a disinfectant label to decide which type of disinfection is suitable for a specific given situation and which method of preparation to choose from methods mentioned on the product's label. In the third task, the students were supposed to determine a proportion of particular elements in different given fertilizers and compare which fertilizer of a given mass is richer in nitrogen - $\mathrm{Ca}\left(\mathrm{NO}_{3}\right)_{2}$ or $\mathrm{NaNO}_{3}$.

\section{Improving the intervention plan}

Although the results were promising (see below), changes in the procedure were made (see below).

\section{Action phase II (April - May 2019)}

The teacher's role (especially the students' guidance through the particular steps) was diminished so the learning tasks were targeted at the students. The tasks were completed with scaffolding in the form of a description of each groups' solution procedure for the teacher to control each group's work easier. Formative feedback methods were introduced. It was above all the "traffic light method" in which students are given cards or cups of three (trafic light) colours to signal their progress or state to the teacher. Green shows they think they know what they are doing, orange shows they feel insecure but resume working, red shows they are either stuck, do not understand the task or face another problem. This method is supposed to develop students' metacognition as well as helping the teacher to orientate in numerous classes (more than 30 students) focusing their attention to those who seem to need it the most at times. ${ }^{49}$ The intervention continued for another two months. After the intervention, the post-test II was realised.

\section{Reflection phase II (June - September 2019) Post-test II (June 2019) \\ After another two months of the intervention's appli- cation, a post-test II was given to the students in order to measure the effectiveness of the teaching approach em- phasizing problem solving strategies.}


Action research evaluation (June - September 2019)

To evaluate the test results, the students were divided into three categories according to the score they achieved. The category of unsuccessful students includes those with a score $\leq 2$. Partially successful students reached 3 or 4 points, the successful students reached $\geq 5$ points. Based on the results, changes to the future plan were made.

\section{4. Data Analysis}

With respect to the data (test scores), a non-parametric test - Friedman's ANOVA was used to evaluate differences between students' test scores in each of the three tests. They were followed by the Wilcoxon's post-hoc test using IBM SPSS Statistics 26. To measure the effect-sizes, $r$ was calculated. Levels of 0.10 are considered a small effect, $0.10-0.30$ a medium and over 0.50 a large effect. ${ }^{50}$ The level of significance was set to 0.01 .

The statistical methods were applied only to the results of the students who took part in all three test phasess $(N=112)$. The rest, such as the comparison of relative improvement in a test, the rate of improvement, etc. were calculated for all the students who took part in two compared tests $(N=136)$.

\section{Results and Discussion}

\section{1. Information About Respondents}

Altogether, 144 students from the first grade of a non-chemical vocational school took part in the action research. All data about students were anonymized. As the action research was conducted without disturbing the normal course of the school year, naturally, not all the students were present in all the lessons during the research. These students were not included in the total sample for the statistics (see Tab. 1).

With an exception of two students who graduated from lower-secondary in 2017, all the rest graduated in 2018. Therefore, they were tested with only a summer break pause from graduating. The presumption of them having mastered the lower-secondary education objectives was therefore valid. The information about the students is shown in Table 1.

Table 1. The number of students in the action research

\begin{tabular}{lcccc}
\hline & $\boldsymbol{N}$ & Girls & Boys & Schools \\
\hline Students in total & 144 & 94 & 50 & 87 \\
Selected students $^{*}$ & 112 & 75 & 37 & 74 \\
\hline
\end{tabular}

* The students who took all three tests, therefore are included in the statistical analysis.

The number of schools the students came from to the upper-secondary school showed the variety of teaching approaches these students underwent. Also, the pre-test re- sults, in a way, reflect lower-secondary chemistry teaching's effectiveness at a considerable number of schools. As far as the students' school success at the beginning of the action research (the first mid-term) was concerned, the overall ( $N$ $=144$ ) mean of the students' school grade was 2.03 (grades from 1 - the best and 5 - the least successful). When only selected students (students who took all three tests; $N=$ 112) were taken into account, the mean of school grades was 2.01The grade distribution is shown in Figure 3.

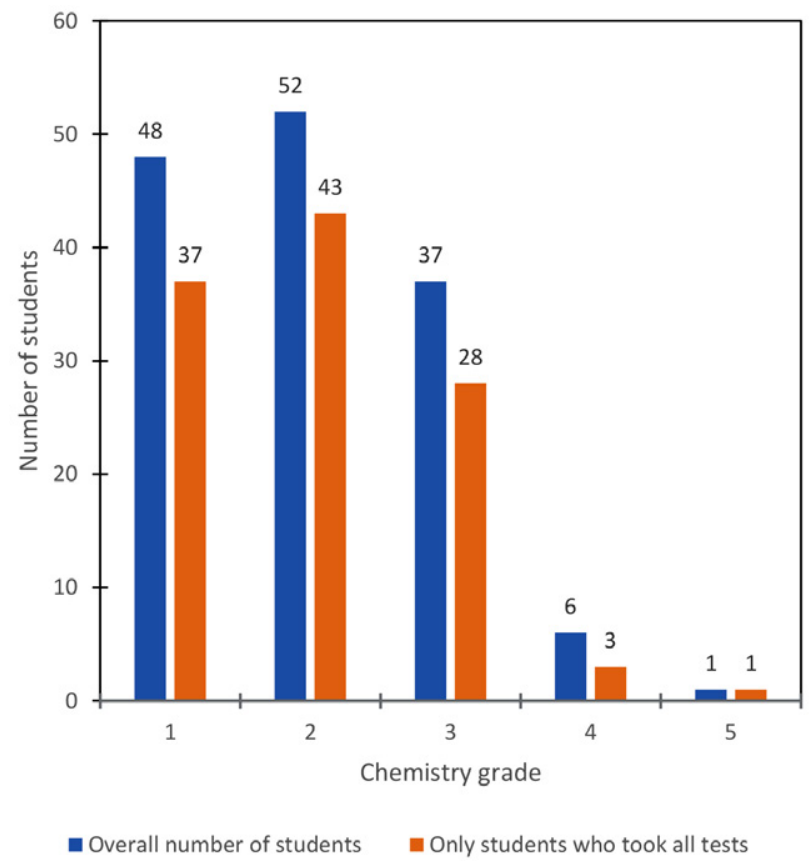

Figure 3. Student distribution according to the school grades

In the whole group of included students there were about $5 \%$ of students with a low school-success (judging by their grades). About $30 \%$ of the students were considered partially-successful and the rest successful. Given the fact non-chemical vocational school chemistry follows only a slightly advanced chemistry curriculum to lower-secondary school, ${ }^{9}$ it was possible to assume the students with better grades will be more successful in the pretest than those with worse grades.

\section{2. Action Research Results in Total}

Figure 4 shows the development of students' test score during the action research. Only results of the stu-

Table 2. The overall test results

\begin{tabular}{lcccc}
\hline & N & Med & Min. & Max. \\
\hline Pre-test & 112 & 1 & 0 & 4 \\
Post-test I & 112 & 2 & 0 & 6 \\
Post-test II & 112 & 3 & 0 & 6 \\
\hline
\end{tabular}


dents' participating in all three tests were included to give a more accurate picture of their performance shifts (see Table 2).

The results showed the unsuccessful students' improvement as an effect of the action research. The scores, as expressed by the students' mean points in the tests, improved from the pre-test to the post-test I and from the post-test I to the post-test II. The Friedman's ANOVA test showed the difference among the three tests is statistically significant $(p<0.001)$. Kendall's $W$ test result $(W=0.54)$ suggests a strong effect of the difference. Particular differences will be described in more detail below test-by-test.

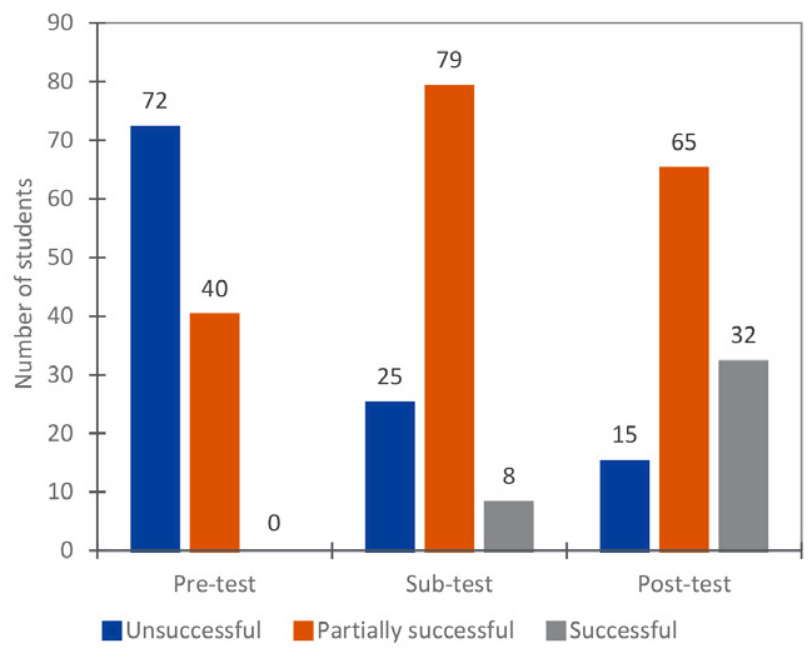

Figure 4. Students' scores in the three tests according to the success group $(N=112)$

Despite the teaching approach emphasizing problem solving strategies proved successful, there were still a considerable number of students who reached the level only partially or did not reach it at all see Figure 4.

\section{Pre-test results}

The students' results in the pre-test are shown in Figure 5. Almost half of them did not receive a single point and were considered unsuccessful. This is in con- trast with their school grade (see Figure 3), as these suggest more than a half of the students were successful in chemistry.

The pre-test results showed that the lower-secondary chemistry objectives were not met by most of the students. $85 \%$ of the students did not manage to identify correct elements according to their description in the text. They did not prove their understanding of the element groups within the table, their ability to identify metals, non-metals and metalloids and only 14\% proved their knowledge and skills in this respect. Considering the students knowledge regarding factors influencing chemistry reaction rate was concerned (task 2), 65,5\% failed to match a particular procedure to the graph of the reaction rate, $28,5 \%$ managed partially (matched the procedures correctly without any or correct explanation) and only $5 \%$ solved the task correctly. As far as the third task - applying compounds' physical property data in the tables - was concerned, $83 \%$ of the students failed to infer the properties, i.e. apply two sources of information to identify the state of the given compounds. Only $16 \%$ of the students managed this task.

This was an important finding for the teacher's attitude towards grading. The fact no student was considered successful (reached 5 or 6 points) in the test, suggests that the tested students had not reached the curricular objective for lower-secondary chemistry education. This result supports the findings by the Czech School Inspectorate: ${ }^{51}$ the students do not possess the knowledge and skills required in this tasks (oriented at the end of compulsory education). The research shows that these results are similar in other school subjects too. Also, these students' low motivation to handle unfamiliar, more complex and challenging tasks proved to be an intervening factor as many of them gave up solving the task when they first encountered a problem. Nevertheless, this form of teaching, when some information is given and students need to apply it to a new situation, meets the contemporary (chemistry) teaching paradigm. ${ }^{48,52}$

There are several possible explanations for this result. First, the curricular objectives as translated to the tasks are too demanding. This would mean the piloting ${ }^{26}$ was not performed thoroughly enough. Second,

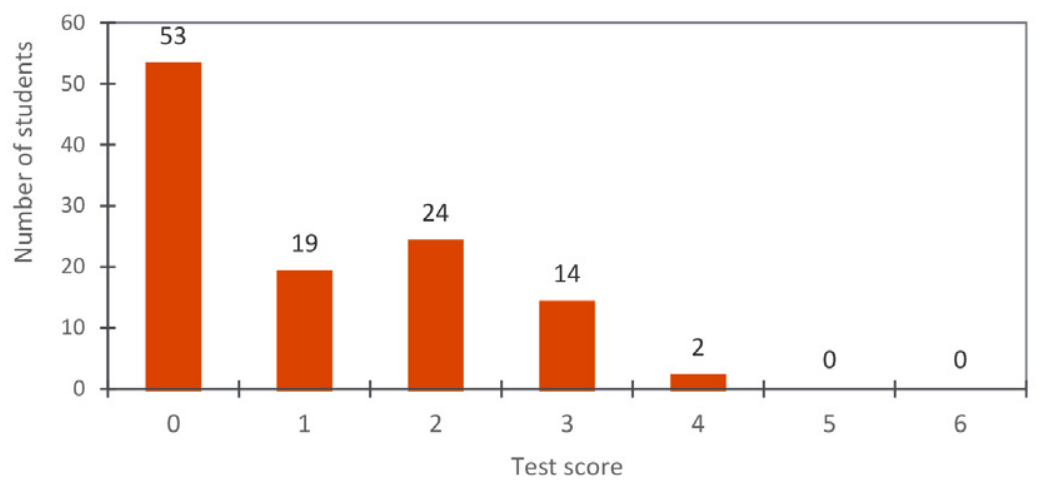

Figure 5. Students' success in the pre-test $(N=139)$ 
non-chemical vocational school students' attitudes are already formed during lower-secondary school attendance with chemistry being not a popular subject $\mathrm{cf},{ }^{53}$ which is reflected not only in their choice of study program, but also in the effort they are willing to put into learning chemistry. ${ }^{9}$ If proven true, this would put PISA and other international tests into serious question. Third, the tested curricular objectives are usually tested right after a topic is finished. In this case, it has been more than half a year (for some topics even longer) since the students covered the topics, therefore the students could have forgotten most of it and failed because of the lack of the necessary content knowledge.

\section{Post-test I results}

After two months of the action (intervention), a post-test I was carried out. Again, three problem tasks of comparable difficulty see ${ }^{40}$ to the pre-test were used. The students could achieve a maximum of six points (see Figure 6).

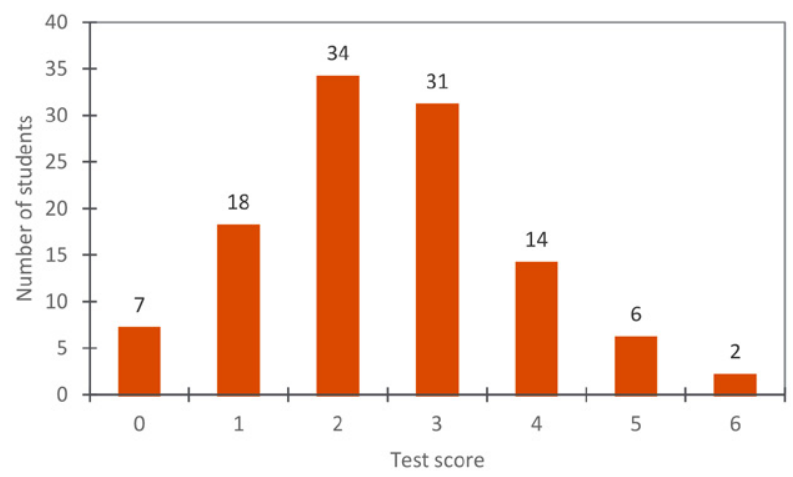

Figure 6. Students' success in the post-test $\mathrm{I}(N=136)$

The teaching approach emphasizing problem solving strategies seems to have a positive effect on the students' results. The number of students with 0 or 1 point diminished rapidly, causing the $33 \%$ of students from the unsuccessful to move into partially successful group. There were also 6 students in the successful group (two students who solved the tasks completely correctly (6 points) and another six with five points in total. A statistically significant difference $(p<.001)$ was found between the pre- and post-test I results. The comparative analysis results are presented in the Table 2 . The effect of the difference $(r=.501)$ is large.

The students' skills seem to have developed, especially in the transfer of the students unsuccessful to successful in the test. More detailed information was received after performing a post-hoc test. The Wilcoxon signed ranks test results show that 82 students improved, 23 achieved the same score and 7 received less points. This shift was mainly caused by 30 (27\%) students improving only by 1 and 2 points (mostly from 0 to 1 or 2 points). In the group of students successful in the post-test I, with an ex- ception of two students who improved from an original 3 to 5 or 6 points, the rest improved from 0,1 or 2 points. Therefore, it is possible to assume the intervention plan targeted all groups of students.

Most of the students whose results worsened in the post-test I received 3 or 4 points in the pre-test and only 2 in the post-test I. With the comparable difficulty of the tasks in mind, this result can be explained by false positive pre-test results. ${ }^{31,41}$

The students who did not score differently in the post-test I or the pre-test mostly remained with 0,1 or 3 points. In the first two groups, the intervention seems not to have affected these students. In case of the latter group, a limited number of these students seems to have been reached and remain in the middle of the point scale.

In spite of the positive shift after the first intervention, $58 \%$ of the students still did not reach at least 3 points (50\% of the points) and are therefore considered unsuccessful. Seven of the eight students from the qualitative (eye-tracking) study were in the unsuccessful group of students after the post-test I. The strategies and problems as identified by apply more to the unsuccessful students. ${ }^{41}$ This is in favour of the action plan with these particular students.

\section{Post-test II results}

Evaluating the second intervention phase was conducted with the use of a post-test II. Again, it consisted of 3 problem tasks very similar to the pre-test. Figure 7 shows an increase in the group of partially successful (3-4 points) and successful (5-6 points) students, together with a decrease in the number of unsuccessful students compared to Figure 6.

There were $25 \%$ unsuccessful, $63 \%$ partially successful, and $27 \%$ successful task 1 solvers. In the second task, $27 \%$ failed, $22 \%$ solved it partially successfully and $51 \%$ successfully. $48 \%$ failed and $48 \%$ succeeded in solving the third task after the intervention.

The Table 2 again shows an overall increase in the students' results. The value of the Friedman's ANOVA test

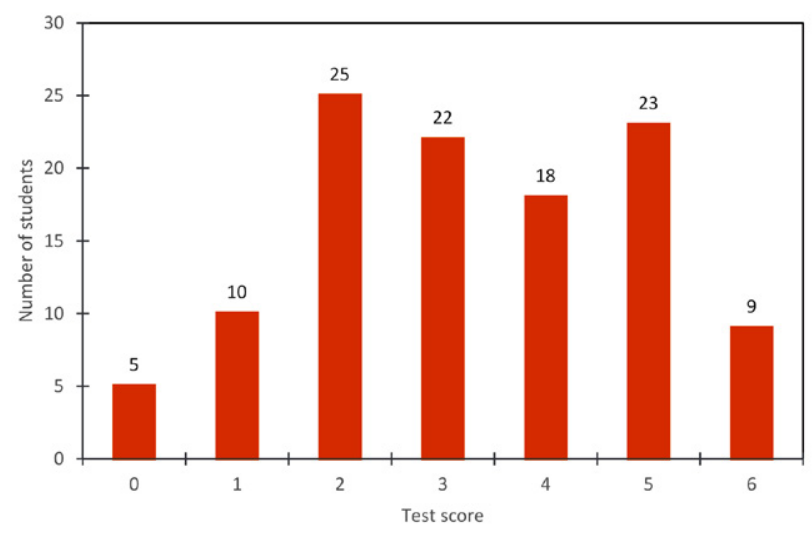

Figure 7. Students' success in the post-test: number of points received $(N=115)$ 
$(p<.001)$ shows the difference is statistically significant. The effect of the difference $(r=0.284)$ was medium.

The post-hoc test's results showed that 67 students improved, 25 received the same number of points and 20 scored worse comparing to the post-test I.

The students who received 5 or six points (61 resp. 39\%) mostly improved from 3 resp. 4 points in the posttest I. Surprisingly, only three students who received 5 or 6 points in the post-test I confirmed their result by reaching the same score in the final test. Two of them even sank into the unsuccessful category with 2 or 1 point in the post-test II.

As far as the group with no shift in their score was concerned, the majority received 2 resp. 3 points (33 resp. $21 \%)$. This, again, could be caused by these students' limits. For most of the students in the group with a negative shift, the decline in score was relatively small. 16 students (47\%) scored 2 points lower and 12 students (35\%) 1 point lower. Several students who succeeded in the post-test I got a lower score in the post-test II ( 7 from 4 points, 5 from 3 points and 4 from 5 points). Only several students sank more dramatically -3 students to 0 and for 4 students to 1 point.

The overall success of the teaching approach emphasizing problem solving strategies was assessed using the pre-test - post-test II comparison. Table 2 shows the overall difference in the students' score. The $\mathrm{p}$ value $(p<0.001)$ showed a statistically significant difference between the two test results. The $\mathrm{r}$-value $(r=0.545)$ showed a large effect. 93 students' results improved, 13 remained unchanged and 6 worsened.

The approach seems have effect on the students with some fundamental knowledge and skills which could be further developed. $56 \%$ of the students whose results did not change received 0 points. Also, most students whose result worsened from the pre- to post-test II (63\% out of all students whose results worsened; $N=16$ ) received no points in the post-test II. As these students achieved only 1 or 2 points in the pre-test, therefore still unsuccessful, the situation is similar to the students who did not score any point in the pre-test. There are two possible explanations of this result. First, a certain indifference towards the influence of school, i.e. the intervention steps is presumed. Apart from aforementioned reading skills, students' misconceptions had been blamed to prevent them from learning chemistry ${ }^{54}$ Second, The intervention built upon certain basic skills. The unsuccessful students might have been below this level. Considering the fact, the research was performed on upper-secondary students, this was not anticipated. The qualitative part of the study revealed that many problems lie, apart from lack of knowledge, in reading and the inability to identify the problem. ${ }^{31}$ For many students, this was corrected by the described intervention. The students' ability to read chemistry texts ${ }^{41}$ seems to have increased by the practice, so did their ability to identify the problem, as well as indicia given in the task for the problem to be solved. ${ }^{55-56}$ As observed in the lessons, experiencing success motivated the students to stay on a task, even if it seemed difficult at the beginning.

The intervention showed that problem-solving skills can be promoted when systematically worked upon. ${ }^{18}$ Focusing on relevant ${ }^{57}$ problems seems more important than just on knowledge that students are often unable to apply. ${ }^{52,58}$

Nevertheless, the results showed there was still a group of students whose abilities could not be improved in the above-described manner. This points to a new, necessary line of research - identification of appropriate intervention underachieving students would benefit from.

\section{Conclusions}

The presented action plan can be considered effective as it helped improve the students' problem-solving skills. At the beginning, only $15 \%$ of the students received at least half of the test points. In the pre-test, the maximal reached score was four points out of six, with almost half of the students receiving no points and another $38 \%$ only one or two points (unsuccessful). The results show the students entering upper-secondary schools mostly did not reach the lower-secondary chemistry curricular objectives with the students' chemistry knowledge and skills on a rather low level. This could be a result of their school choice - vocational schools are usually not chosen by students with the highest academic achievement. The school this research was conducted in, however, belongs among prestigious schools using a student selection process which places the school among the top of its kind in the country. The results showed the students did not understand the basic concepts, e.g. a proton number, electronegativity or conductivity. Also, the students struggled with chemical processes used in real life, such as a chemical reaction or how to prepare a solution. This may serve as an argument for undergoing curricular reform.

The intervention focused on the students' ability to apply the basic knowledge gained from the text and break up the presented problem into partial steps. After the intervention, $65 \%$ of the students achieved more than half points (shift from 15\%), with 30\% students considered successful (from $0 \%$ at the beginning). This shift applied especially to students who proved at least an elementary background (knowledge, strategies, skills). A considerable number of students without this background proven in the pre-test showed no progress after the intervention, which suggests alternative approach is needed for these students' improvement.

The overall positive effect of the intervention could be caused by the foundation received from the earlier performed eye-tracking study completed with retrospective think-aloud. It helped identify reading problems in particular, but also other limiting strategies and helped to shape 
the intervention to fit the students' needs as well as possible.

Another favorable aspect of the intervention was the combination of using problem tasks, expertly evaluated (and if needed altered) groupwork, gradually phased problem-solving steps and formative assessment, which seems to have led to the positive results. This approach led to error retrieval in quite a short period of time ( 2 months, 1 lesson a week).

Based on the experience with the tasks, their more frequent use can be recommended by the teacher. The question of the task results' evaluation can be solved either by using open-ended questions or multiple-tier tasks to limit the false-positive results.

With enough data about students' problem-solving skills gathered from several studies like this, the qualitative phase (think aloud supported with eye-tracking study) could be omitted. Students could be tested only to find their actual state of knowledge and skills based on a pretest. Later, a set of "bespoke" tasks (different versions of the tasks based on the pre-test) could be used in a similar way.

\section{Limitations}

Several limitations in this study were caused by the research method used. The typical limit of action research is that the teacher is the only researcher. ${ }^{58}$ The effect was eased by a researcher's participation. Another limitation is related to the results' vigor. They are limited by a low number of respondents. It exceeds usual action research samples; however, it does not enable a full generalization of the results. Also, the respondent choice - students from one vocational school - may influence the results because the students' focus may divert from science cf. ${ }^{9}$ On the other hand, the sample represents students from various lower-secondary schools (87) and therefore has the potential to reflect reality. Another limit of the study is the lack of repeatability and rigour as the feedback the teacher gave students reflected their actual problems. Nevertheless, there are certain steps which can be repeated with other students with no changes. By repeating the process, the range of problem-solving skills is expected to become clear enough so the pre-test's qualitative part could be omitted, and the procedure run universally.

In addition, the results could be limited by using only two points to score students' results in each task. Despite following the same approach used by PISA, assigning more points to each task could help distinguish the students more.

Last but not least, a limit of the intervention needs to be discussed. Despite teachers cannot always attract and have influence on all the students, this considerably high number of students seemingly unaffected by the intervention is a group which requires more attention in the future. Apart from a typical sample for qualitative eye-tracking study (successful vs. unsuccessful, novice vs. experts), these could be given a special attention. A follow up inter- vention which would target these students better would complete the results.

\section{Implications}

For educators

As the problem-solving ability is one of $21^{\text {st }}$ century competencies, ${ }^{14}$ teachers should build their lessons around problem tasks which on one hand contain subject-matter of a corresponding topic, and, on the other hand, develop students' problem-solving skills. Having students work in groups further adds to other skills such as groupwork and communication. Moreover, using the traffic-light method of formative feedback proved to be an effective tool in classroom instruction.

\section{For researchers}

A cooperation of a teacher with a researcher proved to fill the gap between educational research and the implemented curriculum. The research results relevant to the lesson instruction had their value for the teacher. In addition, the researcher could experience an unusually instant effect of the offered evidence-based improvements.

The action research proved to be an effective tool bringing teaching and research together. Being able to analyze students' results in more detail and literally dissect their problem and focus on it in ordinary teaching enabled the teacher to look beyond everyday practice. On the other hand, the researcher gained more insight into the classroom's dynamics as well as other intervening factors which would remain hidden in ordinary research.

The next steps in this direction will target the very problem of the students' performance on the tasks. They need to be divided into smaller parts and studied separately to provide more information not only about the already studied strategies students use, but also their reading performance, the effect of visual representations and even used text $\left(c f .{ }^{59}\right)$.

\section{Acknowledgments}

This work has been supported by the Charles University Research Centre program No. UNCE/HUM/024.

\section{Declaration of interest}

As it was action research, the first author was teaching the students. No other conflict is to declare.

\section{Reference}

1. N. Costa, L. Marques, R. Kempa. Res. Sci. Tech. Educ. 2000, 18, 37-44. DOI:10.1080/713694955

2. R. Vanderlinde, J. van Braak. Brit. Educ. Res. J. 2010, 36, 299316. DOI:10.1080/01411920902919257

3. W. Carr, Becoming critical: Knowing through action research. Deakin University: Geelong, 1983. 
4. M. Souto-Manning. Childhood Educ. 2012, 88, 54-56. DOI:10.1080/00094056.2012.643726

5. M. Stuckey, I. Eilks. Chemistry under Your Skin? Experiments with Tattoo Inks for Secondary School Chemistry Students 2015, 92, 129-134. DOI:10.1021/ed400804s

6. M. Stuckey, I. Eilks. J. Chem. Res. Pract. 2014, 15, 156-167. DOI:10.1039/C3RP00146F

7. C. A. Mertler, Action research: Teachers as researchers in the classroom. Sage: 2009.

8. L. Cohen, L. Manion, K. Morrison, Educational research methodology. Metaixmio: Athens, 1994.

9. M. Rusek. Výzkum postojů žáků středních škol k výuce chemie na základní škole. [Vocational school students' attitudes towards chemistry education at lower-secondary schools research]. Doctoral thesis, Univerzita Karlova, Praha, 2013.

10. M. Rusek. Scientia Educ. 2014, 5, 13-29.

DOI:10.14712/18047106.113

11. Rámcový vzdělávací program pro gymnázia. [Framework educational programme for grammar schools]; Výzkumný ústav pedagogický v Praze: Praha, 2007, p 100.

12. Rámcový vzdělávací program pro obor vzdělání 78-42-M/02 Ekonomické lyceum. [Framework educational programme for educational field 78-42-M/02 Economic lyceum]; NÚOV: Praha, 2007.

13. R. Elmas, M. Rusek, A. Lindell, P. Nieminen, K. Kasapoglu, M. Bílek. Chem. Educ. Res. Pract. 2020, 21, 839-851.

DOI:10.1039/D0RP00058B

14. J. A. Bellanca, 21st century skills: Rethinking how students learn. Solution Tree Press: 2010.

15. B. Sket, S. A. Glazar, J. Vogrinc. Acta Chim. Slov. 2015, 62, 462-472. DOI:10.17344/acsi.2014.1148

16. R. F. Angawi. J. Chem. Educ. 2014, 91, 823-829. DOI:10.1021/ed4004436

17. E. Hejnová, M. Kekule. Scientia Educ. 2018, 9, 102-116. DOI:10.14712/18047106.1018

18. A. H. Johnstone. Uni. Chem. Educ. 2001, 5, 12-18. DOI:10.7748/mhp.4.5.18.s16

19. A. H. Johnstone, Introduction. In Creative Problem Solving in Chemistry, Wood, C.; Sleet, R., Eds. The Royal Society of Chemistry: London, 1993.

20. N. Reid, M.-J. Yang. Res. Sci. Technol. Educ. 2002, 20, 83-98. DOI:10.1080/02635140220130948

21. S. K. Reed. Educ. Psychol. Rev. 2016, 28, 691-716. DOI:10.1007/s10648-015-9343-1

22. D. H. Jonassen. Eudc. Tech. Res. 1997, 45, 65-94. DOI:10.1007/BF02299613

23. Z. Haláková, M. Prokša. Two Kinds of Conceptual Problems in Chemistry Teaching 2007, 84, 172.

DOI:10.1021/ed084p172

24. OECD, PISA 2015 Results (Volume I). 2016.

25. OECD, PISA 2018 Results (Volume I). 2019.

26. K. Vojír̆, J. Holec, M. Rusek In: Rusek, M., Stárková, D., Bílková Metelková, I. (Eds.) Prrírodopisné a chemické úlohy pro základni vzdělávání a jejich metodické komentáře: Projektové vyučování v prírodovědných předmětech XIV., Praha, 2017, pp 221-228.
27. K. Koreneková. Výzkum strategií uplatňovaných žáky při řešení problémových úloh $\mathrm{z}$ chemie. [Research of strategies applied by students during chemistry problem-tasks' solving]. Master thesis, Praha, 2018.

28. I. V. Mullis, A. M. Kennedy, M. O. Martin, M. Sainsbury, PIRLS 2006 Assessment Framework and Specifications: Progress in International Reading Literacy Study. ERIC: 2004.

29. S. Greiff, S. Wüstenberg, B. Csapó, A. Demetriou, J. Hautamäki, A. C. Graesser, R. Martin. Educ. Res. Rev. 2014, 7483. DOI:10.1016/j.edurev.2014.10.002

30. G. Polya, How to solve it: A new aspect of mathematical method. Princeton university press: New Jersey, 2004.

31. M. Tóthová, M. Rusek, V. Chytrý. J. Chem. Educ. 2021, 98, 1831-1840. DOI:10.1021/acs.jchemed.1c00167

32. M. L. Lai, M. J. Tsai, F. Y. Yang, C. Y. Hsu, T. C. Liu, S. W. Y. Lee, M. H. Lee, G. L. Chiou, J. C. Liang, C. C. Tsai. Educ. Res. Rev. 2013, 10, 90-115.

DOI:10.1016/j.edurev.2013.10.001

33. M. Slapničar, V. Tompa, I. Devetak, S. A. Glažar, J. Pavlin, Using an Eye-Tracker to Study Students' Attention Allocation When Solving a Context-Based Problem on the Sublimation of Water. In Applying Bio-Measurements Methodologies in Science Education Research, Devetak, I., Glažar, S. A., Eds. Springer International Publishing: Cham, 2021, pp 107-127. DOI:10.1007/978-3-030-71535-9_6

34. M. Slapničar, V. Tompa, S. A. Glažar, I. Devetak, J. Pavlin. Acta Chim. Slov. 2020, 67, 904-915.

DOI:10.17344/acsi.2020.5908

35. M. Rodemer, J. Eckhard, N. Graulich, S. Bernholt. J. Chem. Educ. 2020, 97, 3530-3539.

DOI:10.1021/acs.jchemed.0c00418

36. R. Evans, The Human Side of School Change: Reform, Resistance, and the Real-Life Problems of Innovation. The Jossey-Bass Education Series ERIC: 1996.

37. M. A. Just, P. A. Carpenter. Psychol. Rev. 1980, 87, 329-354. DOI:10.1037/0033-295X.87.4.329

38. M. Van Someren, Y. Barnard, J. Sandberg, The think aloud method: a practical approach to modelling cognitive. London Academic Press: London, 1994.

39. G. W. Kuhne, B. A. Quigley. New Dir. Adult Cont. Educ. 1997, 73, 23-40. DOI:10.1002/ace.7302

40. J. Holec, M. Rusek, Metodické komentáře a úlohy ke Standardìm pro základní vzdělávání - chemie. [Methodological comments and tasks to Standards for lower-secondary education - chemistry], NÚV: Praha, 2016, p 105.

41. M. Rusek, K. Koreneková, M. Tóthová In: Rusek, M., Vojíř, K. (Eds.) How Much Do We Know about the Way Students Solve Problem-tasks: Project-based Education and Other Activating Strategies in Science Education XVI., Prague, 2019, pp 98-104.

42. A. S. Dhillon. Sci. Educ. 1998, 82, 379-405. DOI:10.1002/ (SICI) 1098-237X(199806)82:3<379::AID-SCE5>3.0.CO;2-9

43. A. S. Posamentier, S. Krulik, Problem-solving strategies for efficient and elegant solutions, grades 6-12: a resource for the mathematics teacher. Corwin press: 2008.

44. M. D. Lew, H. G. Schmidt. Adv. Health Sci. Educ. 2011, 16, 529. DOI:10.1007/s10459-011-9298-Z 
45. J. Skalková, Obecná didaktika. [General didactics], Grada: Praha, 2007.

46. A. Chupáč. Ped. Or. 2008, 18, 73-82. DOI:10.3233/BME-2008-0510

47. J. T. Wilson, I. Chalmers Neubauer. J. Chem. Educ. 1988, 65, 996. DOI:10.1021/ed065p996

48. V. Talanquer, J. Pollard. Chem. Educ. Res. Pract. 2010, 11, 74-83. DOI:10.1039/C005349J

49. P. Black, D. Wiliam, Changing teaching through formative assessment: Research and practice. In Formative assessment: Improving learning in secondary classrooms, Looney, J., Ed. OECD: Paris, 2005, pp 223-240.

50. J. Cohen. Psych. bul. 1992, 112, 155.

DOI:10.1037//0033-2909.112.1.155

51. Kvalita a efektivita vzdělávání a vzdělávací soustavy ve školním roce 2017/2018. [Quality and effectivity of education and educational system in 2017/2018]; Česká školní inspekce: Prague, 2018.

52. A. H. Johnstone. J. Chem. Educ. 2010, 87, 22-29. DOI:10.1021/ed800026d
53. T. Jarvis, A. Pell. J. Res. Sci. Teach. 2002, 39, 979-1000. DOI:10.1002/tea.10055

54. M. B. Nakhleh. J. Chem. Educ. 1992, 69, 191-196. DOI:10.1021/ed069p191

55. P. S. Steif, J. M. Lobue, L. B. Kara, A. L. Fay. J. Eng. Educ. 2010, 99, 135-142.

DOI:10.1002/j.2168-9830.2010.tb01050.x

56. A.-M. Hoskinson, M. D. Caballero, J. K. Knight. CBE-Life Sci. Educ. 2013, 12, 153-161.

DOI:10.1187/cbe.12-09-0149

57. M. Stuckey, A. Hofstein, R. Mamlok-Naaman, I. Eilks. Stud. Sci. Educ. 2013, 49, 1-34.

DOI:10.1080/03057267.2013.802463

58. P. Gibbs, P. Cartney, K. Wilkinson, J. Parkinson, S. Cunningham, C. James-Reynolds, T. Zoubir, V. Brown, P. Barter, P. Sumner. Educ. Act. Res. 2017, 25, 3-22.

DOI:10.1080/09650792.2015.1124046

59. M. Rusek, K. Vojír. Chem Educ Res Pract 2019, 20, 85-94. DOI:10.1039/C8RP00141C

\section{Povzetek}

Raziskave o spretnostih problemskega reševanja po vsem svetu kažejo, da je še veliko možnosti za izboljšave. Namen te študije je bil izboljšati spretnosti problemskega reševanja pri urah kemije pri srednješolcih. Dijaki so opravili predtest s problemskimi nalogami, ki je bil osredotočen na njihovo konceptualno znanje o periodnem sistemu, sposobnost uporabe znanja o dejavnikih, ki vplivajo na hitrost kemijske reakcije, in lastnostih spojin. Večina učencev (72 od 112) nalog ni uspela rešiti. Zato je bila zasnovana intervencija, ki je temeljila na študiji $\mathrm{z}$ uporabo sledenja očem $\mathrm{v}$ kombinaciji $\mathrm{z}$ glasnim razmišljanjem. Vključevala je delo učencev pri reševanju kemijskih problemskih nalog (podobnih PISA nalogam), ki temeljijo na kontekstu, s posebnimi podpornimi ukrepi. Učitelj je zagotovil formativno ocenjevanje, ki je spodbujalo učenčeve strategije. Učinek intervencije je bil ponovno ocenjen $\mathrm{z}$ uporabo problemskih nalog $\mathrm{v}$ dveh naknadnih testih. Rezultati so pokazali, da je akcijski načrt uspešno pomagal večini učencev pri doseganju nadpovprečnih rezultatov na testu. Povečalo se je tudi razmerje uspešnih reševalcev, delež neuspešnih pa se je občutno zmanjšal.

Except when otherwise noted, articles in this journal are published under the terms and conditions of the Creative Commons Attribution 4.0 International License 